\title{
Targeting essential pathways in trypanosomatids gives insights into protozoan mechanisms of cell death
}

\author{
Despina Smirlis ${ }^{1 *}$, Michael Duszenko² , Antonio Jiménez Ruiz ${ }^{3}$, Effie Scoulica ${ }^{4}$, Patrick Bastien ${ }^{5}$, Nicolas Fasel ${ }^{6}$, \\ Ketty Soteriadou'
}

\begin{abstract}
Apoptosis is a normal component of the development and health of multicellular organisms. However, apoptosis is now considered a prerogative of unicellular organisms, including the trypanosomatids of the genera Trypanosoma spp. and Leishmania spp., causative agents of some of the most important neglected human diseases. Trypanosomatids show typical hallmarks of apoptosis, although they lack some of the key molecules contributing to this process in metazoans, like caspase genes, Bcl-2 family genes and the TNF-related family of receptors. Despite the lack of these molecules, trypanosomatids appear to have the basic machinery to commit suicide. The components of the apoptotic execution machinery of these parasites are slowly coming into light, by targeting essential processes and pathways with different apoptogenic agents and inhibitors. This review will be confined to the events known to drive trypanosomatid parasites to apoptosis.
\end{abstract}

\section{Introduction}

From the mid-nineteenth century, many observations have indicated that cell death plays a considerable role during physiological processes of multicellular organisms, particularly during embryogenesis and metamorphosis [1]. The term programmed cell death (PCD) was introduced in 1964, proposing that cell death during development is not of accidental nature but follows a sequence of controlled steps leading to locally and temporally defined self-destruction [2], in contrast to necrosis, which is a form of cell-death that results from acute tissue injury and provokes an inflammatory response. It is evident that death may occur through different mechanisms leading to distinct morphologies.

Consequently, different types of PCD have been described, the most important forms being apoptosis and autophagic cell death [3]. The term apoptosis describes biochemical processes and morphological features leading to controlled cellular self-destruction such as rounding-up of the cell, condensation of the

\footnotetext{
* Correspondence: penny@pasteur.gr

'Laboratory of Molecular Parasitology, Department of Microbiology, Hellenic

Pasteur Institute, 127 Bas. Sofias Ave., 11521 Athens, Greece

Full list of author information is available at the end of the article
}

chromatin, fragmentation of the nucleus (karyorhexis), loss of the mitochondrial membrane potential $(\Delta \Psi \mathrm{m})$, plasma membrane blebbing, and others [4], whereas autophagy is the type of cell death that occurs without chromatin condensation, but often accompanied by massive autophagic vacuolization of the cytoplasm [5]. In mammalian cells the two major apoptotic pathways are the "intrinsic" pathway, involving mitochondrial membrane permeabilisation regulated by the members of the $\mathrm{Bcl} 2 / \mathrm{Bax}$ protein family, and the transmembrane "extrinsic" pathway comprising of activation of death receptors (DRs), via the TNF superfamily of DRs [6]. Despite the fact that these two pathways are relatively distinct, their co-existence and cross-talk is also possible [7].

Although it was initially assumed that apoptosis arose with multicellularity, there is now increasing experimental evidence that similar mechanisms are operative in trypanosomatids of the genera Trypanosoma spp. (T. brucei and T. cruzi) and Leishmania spp. These parasites display complex life cycles, with multiple differentiation forms alternating between mammalian and insect hosts. Trypanosomatids are the causative agents of diseases such as Kala-azar (visceral leishmaniasis), 
cutaneous and mucocutaneous leishmaniasis, Chagas disease (American trypanosomiasis) and African sleeping sickness (African trypanosomiasis), diseases affecting more than 27 million people worldwide [8].

Different types of cell death exist in these unicellular parasites, including apoptosis and autophagic cell death (reviewed in $[9,10]$ ), triggered in response to diverse stimuli. In trypanosomatids, the former is induced by different stimuli such as heat shock [11-14], reactive oxygen species (ROS) [15-23], antiparasitic drugs [10,24-65], prostaglandins [66], starvation [67-69], antimicrobial peptides [70,71], antibodies [72], serum as a source of complement $[19,73]$, and mutations in cellcycle regulated genes [74] (See additional file 1: Table S1). Once apoptosis is triggered, a cascade of events common to mammalian apoptosis takes place such as production of reactive oxygen species (ROS) and lipid peroxidation, increase in cytosolic $\mathrm{Ca}^{2+}$ levels, changes in mitochondrial membrane potential $(\Delta \Psi \mathrm{m})$, exposition of phosphatidylserine in the outer leaflet of the plasma membrane, maintenance of an intact plasma membrane until late stages of the process, release of cytochrome c, and induction of proteases and DNA cleavage (reviewed in $[75,76]$ ) (See additional file 1: Table S1).

Although these trypanosomatids show the common outcomes of apoptosis as compared with mammalian apoptosis, the absence of homologues to mammalian key regulatory or effector molecules of apoptosis (like TNF-related family of receptors, Bcl-2 family members and caspases) indicates that the pathways of apoptosis are in part distinct in these divergent eukaryotes. However, despite the lack of these molecules, trypanosomatids appear to have the basic machinery to commit suicide.

Trypanosomatids also possess a functional autophagic system (reviewed in [77-79]) that appears to be essential for differentiation and for parasite maintenance and survival $[67,80,81]$, being activated during differentiation, starvation-induced stress [67,80-82], treatment with different drugs [10,83-85] and antimicrobial peptides [86-88]. Although autophagy may also lead to cell death, it is generally regarded as a catabolic survival mechanism.

For this reason, this review will not describe autophagic cell death in trypanosomatids but will be confined to the components of the basic machinery that these parasites possess to commit suicide, and the pathways and/ or biological processes that, when deregulated, drive these protozoan parasites to die in a controlled manner. Obeying the recommendations of the nomenclature commission of cell death [3], we use the term apoptosis here for an induced cell death in trypanosomatids that shows a considerable number of apoptosis hallmarks.

\section{Mitochondrial dysfunction in trypanosomatid apoptosis}

Mitochondria have a central role in metazoan apoptotic cell death, as they are involved in the active control of apoptosis at several levels including the release of proapoptotic proteins [89]. The dysfunction of mitochondria is one of the hallmarks of apoptosis often associated with changes in $\Delta \Psi \mathrm{m}$-a key indicator of mitochondrial function that maybe either a consequence of or an early requirement for apoptosis [90,91].

In trypanosomatids too, many apoptogenic agents or stresses, are associated with a dysfunction of the unique mitochondrion of these organisms indicated by the changes in $\Delta \Psi \mathrm{m}$ (See additional file 1: Table S1). In this respect, the antiparasitic activity of many drugs is mediated by the loss of mitochondrial $\Delta \Psi \mathrm{m}$ (See additional file 1: Table S1). Not only drug treatment but also physiological stress conditions may lead to apoptosis with changes in $\Delta \Psi \mathrm{m}$, for example: nutrient deprivation in stationary phase $L$. donovani promastigote cultures [92], heat stress in L. infantum promastigotes [12], high density cultures producing prostaglandin D2 in T. brucei $[17,66]$, or prolonged endoplasmic reticulum (ER) stress in T. brucei parasites [93] (Figure 1, See additional file 1: Table S1).

The precise and coordinated function of the trypanosomatid mitochondrial respiratory chain complexes is a prerequisite for sustaining the proper mitochondrial potential (reviewed in [94]). Hence, inhibitors of respiratory complexes II $[95,96]$ and III [96] resulted in the dissipation of $\Delta \Psi \mathrm{m}$, whereas complex I inhibition in L. donovani promastigotes, resulted in mitochondrial membrane hyperpolarisation [96]. On the contrary, increase in respiration rates and the concomitant generation of superoxide radicals by heat shock also induced apoptosis in L. infantum promastigotes and resulted in mitochondrial membrane hyperpolarisation [12]. Interestingly, this indicates that both an increase and a decrease in respiration and both hyperpolarisation and loss of $\Delta \Psi \mathrm{m}$ maybe linked with apoptosis in trypansomatids demonstrating the importance of maintenance of proper $\Delta \Psi \mathrm{m}$ in these parasites [96] (Table 1). Although the precise mitochondrial contribution to apoptosis awaits further elucidation the above data reinforce the conception that mitochondrial dysfunction and apoptosis in trypanosomatids are closely associated.

Mitochondrial dysfunction and apoptosis are often initiated in mammalian cells by the mitochondrial outer membrane permeabilisation (MMP) regulated by proapoptotic Bcl-2 family members [97]. No Bcl-2 family members with significant similarity to their mammalian counterparts are encoded by the genome 


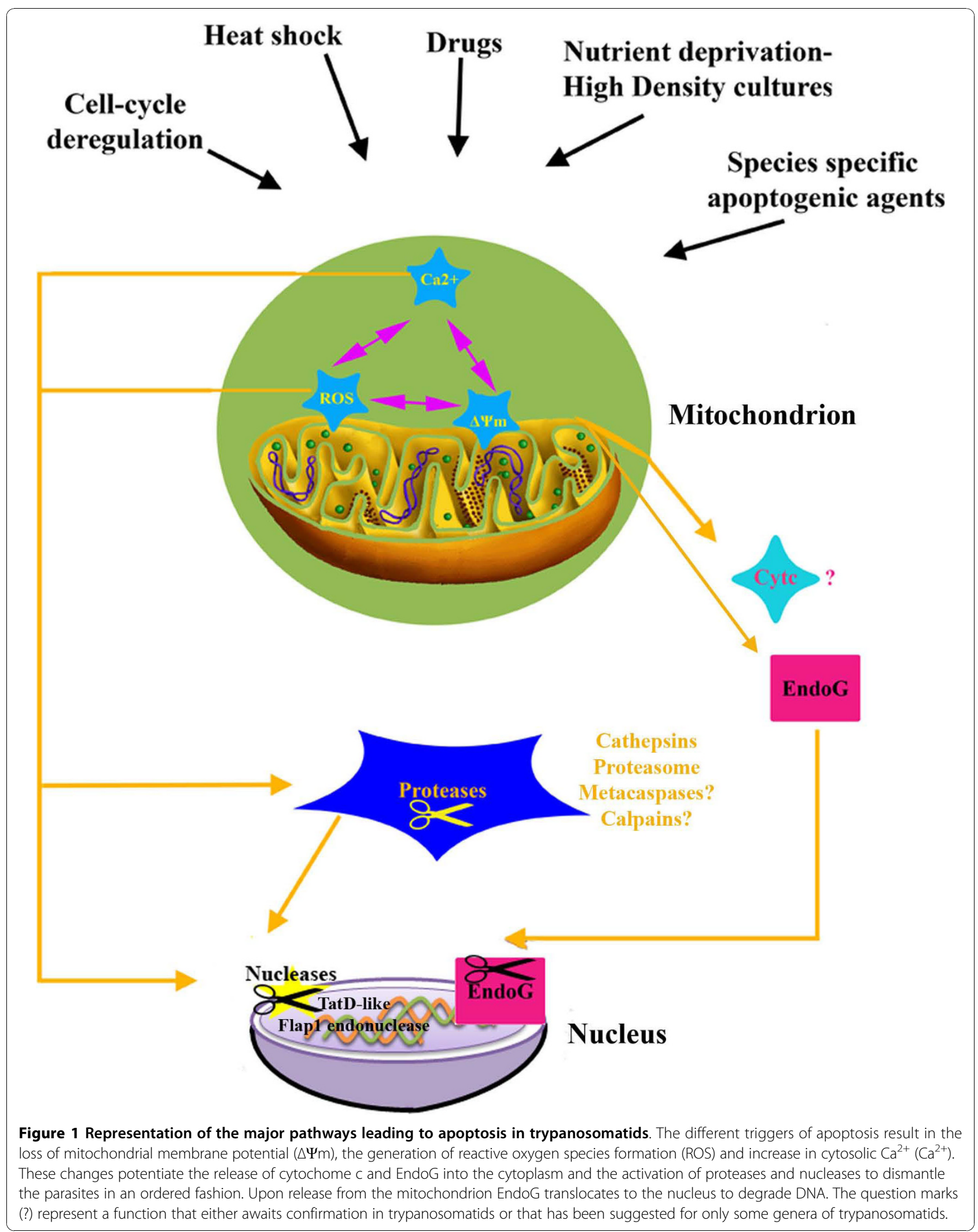


Table 1 Proteins in essential for survival processes, mitochondrial changes and effectors associated with trypansomatid apoptosis

\begin{tabular}{|c|c|c|}
\hline $\begin{array}{l}\text { Proteins in essential processes } \\
\text { associated with apoptosis }\end{array}$ & Mitochondrial changes associated with apoptosis & Effectors of apoptosis \\
\hline $\begin{array}{l}\text { Proteins associated with the cell-cycle } \\
\text { Prohibitin (T. brucei) } \\
\text { RACK (T. brucei) } \\
\text { QM (T. brucei) } \\
\text { PKC (L. donovani) } \\
\text { GSK-3 (L. donovani) } \\
\text { CRK3 (L. donovani) }\end{array}$ & $\begin{array}{l}\text { Respiration and } \Delta \Psi \mathrm{m} \\
\text { Increase, Decrease }\end{array}$ & $\begin{array}{l}\text { Proteases } \\
\text { Cathepsin-like proteases } \\
\text { (CPA, CPB, CPC) } \\
\text { (L. major, L. mexicana) }\end{array}$ \\
\hline $\begin{array}{l}\text { Proteins associated with proliferation } \\
\text { and cell division } \\
\text { Centrin (L. donovani) } \\
\text { EF-1 } \alpha \text { (T. cruzi) }\end{array}$ & $\begin{array}{l}\text { Mitochondrial membrane permeability } \\
\text { ROS by lipid peroxidation } \\
\Delta \mathbf{\Psi} \text { by mitochondrial matrix condensation } \\
\text { Bcl-2 functional homologues }\end{array}$ & $\begin{array}{l}\text { Proteasomal proteases } \\
\text { (L. amazonensis) }\end{array}$ \\
\hline $\begin{array}{l}\text { Proteins involved in DNA replication } \\
\text { Topoisomerases (Leishmania spp.) }\end{array}$ & $\begin{array}{l}\text { Mitochondrial release of pro-apoptotic proteins } \\
\text { Cytochrome } c^{c} \\
\text { EndoG }\end{array}$ & $\begin{array}{l}\text { Metacaspases } \\
\text { (T. cruzi, L. donovani) }\end{array}$ \\
\hline $\begin{array}{l}\text { Proteins involved in nucleocytoplasmic } \\
\text { transport } \\
\text { Ran }(T . \text { brucei) } \\
\text { RanBP1 (T. brucei) } \\
\text { CAS (T. brucei) } \\
\text { NTF-2 (T. brucei) }\end{array}$ & $\begin{array}{l}\Delta \Psi \mathrm{m}, \mathbf{R O S} \text { and Ca2+ interplay } \\
\text { Trigger } \rightarrow \text { Cytosolic Ca2+ elevation } \rightarrow \text { Ca2+ entry into mitochondrion } \\
\rightarrow \text { Dissipation of } \Delta \Psi \mathrm{m} \rightarrow \text { ROS }\end{array}$ & $\begin{array}{l}\text { Nucleases } \\
\text { EndoG } \\
\text { (Leishmania spp.) }\end{array}$ \\
\hline $\begin{array}{l}\text { Proteins in cytoskeletal dynamics } \\
\text { Tubulins } \\
\text { (L. donovani, T. brucei) }\end{array}$ & $\begin{array}{l}\text { Trigger } \rightarrow \text { ROS } \rightarrow \text { lipid peroxidation- } \rightarrow \text { elevation of cytosolic } \mathrm{Ca}^{+} \rightarrow \\
\text { Dissipation of } \Delta \Psi \mathrm{m}\end{array}$ & $\begin{array}{l}\text { TatD-like endonuclease } \\
\text { (L. donovani) }\end{array}$ \\
\hline $\begin{array}{l}\text { Proteins in other processes } \\
\text { SIR2 deacetylase } \\
\text { (L. infantum) }\end{array}$ & Trigger $\rightarrow \mathrm{ROS} \rightarrow \Delta \Psi \mathrm{m} \rightarrow$ intracellular Ca2+ elevation & $\begin{array}{l}\text { Flap-endonuclease-1 } \\
\text { (L. donovani) }\end{array}$ \\
\hline
\end{tabular}

a. Apoptosis is triggered by agents interfering with tubulin polymerization

b. Awaits confirmation

c. Unknown function in trypanosomatid apoptosis

In brackets, the genus or the species involved.

of trypanosomatids, although functional homologues of these proteins may exist in trypanosomatids. To address this question, Arnoult et al. mixed human recombinant Bax-a Bcl-2 family member that induces MMP in mammalian cells via interaction with antiapoptotic family members $[98,99]$ - with $L$. major intact mitochondria [100]. Bax was able to induce pore formation in intact $L$. major mitochondria, followed by a rapid release of cytochrome c [100]. In addition, ectopic expression of mammalian members of the Bcl-2 family, i.e. the antiapoptotic $\mathrm{Bcl}-\mathrm{X}_{\mathrm{L}}$ and the proapoptotic Hrk, either reduced or increased the number of $L$. infantum promastigotes undergoing apoptosis respectively, upon treatment with eldefosine [24]. Bcl- $\mathrm{X}_{\mathrm{L}}$ was also able to partially reverse heat-shock induced cell death in L. infantum promastigotes [11]. In line with the above, ectopic expression of Bax in T. brucei induced loss of $\Delta \Psi \mathrm{m}$ and release of cytochrome $\mathrm{c}$ [101]. Evidence therefore suggests that functional homologues of Bcl-2 family members may exist in trypanosomatids (Table 1). Overall, it appears that apoptosis maybe initiated from the mitochondrion in trypanosomatids, by certain death signals, as it occurs in metazoan mitochondrial mediated apoptosis.

\section{Calcium, $\Delta \Psi \mathrm{m}$, and ROS interplay in trypanosomatid apoptosis: a mitochondrial love- hate triangle}

ROS-products formed during the normal metabolism or resulting from xenobiotic exposure- and $\mathrm{Ca}^{2+}$ signals together are involved in a variety of vital cell functions and thus are necessary for cell survival. However, more recently it has become clear that cellular ROS and $\mathrm{Ca}^{2+}$ overload can cause cytotoxicity and trigger either apoptotic or necrotic cell death $[102,103]$. ROS species and imbalance of calcium homeostasis, also contribute to apoptosis in trypanosomatids, and this occurs via more than one pathway (Figure 1, Table 1; reviewed in $[76,94])$.

In the first pathway, the trigger induces cytosolic $\mathrm{Ca}^{2+}$ elevation. $\mathrm{Ca}^{2+}$ enters the mitochondrion and dissipates $\Delta \Psi \mathrm{m}$. Preceding or following the $\Delta \Psi \mathrm{m}$, ROS are generated by mitochondria via oxidative phosphorylation. These events finally lead to the execution of apoptosis. This pathway has been reported in T. cruzi epimastigotes when exposed to fresh human serum [19]. Upon exposure to fresh human serum, the assembly membrane attack complex resulting from complement activation, allowed the influx of $\mathrm{Ca}^{2+}$, and consequently 
excessive mitochondrial $\mathrm{Ca}^{2+}$ accumulation [19]. Mitochondrial $\mathrm{Ca}^{2+}$ overload resulted in the loss of $\Delta \Psi \mathrm{m}$ and increased superoxide anion production [19]. This connection between mitochondrial $\mathrm{Ca}^{2+}$ overload and ROS generation has also been demonstrated in mammalian systems [104-106].

A second pathway has been described in which the trigger induces ROS formation, which in turn results in lipid peroxidation. Lipid peroxidation affects membrane fluidity and/or the function of calcium channels, disturbing the calcium homeostasis and thus resulting in the elevation of cytosolic $\mathrm{Ca}^{2+}$ and the loss of $\Delta \Psi \mathrm{m}$. This in turn induces the execution of apoptosis. This pathway has been unraveled by treating $L$. donovani promastigotes with thenoyltrifluoro-acetone (a respiratory chain complex II inhibitor) [96], camptothecin or curcumin [26,51] or with hydrogen peroxide [20]. ROS production resulted in an elevation of the cytosolic $\mathrm{Ca}^{2+}$ levels due to opening of non-selective and L-type voltage-gated ion channels in the plasma membrane [20,26,51]. Elevation of cytosolic calcium levels led to the uncoupling of mitochondrial oxidative phosphorylation, to the release of cytochrome $\mathrm{c}$ into the cytosol and directed promastigotes to follow the executionary pathway of apoptosis [15,26,51]. In T. brucei, ROS production has been reported to generate $\mathrm{Ca}^{2+}$ homeostasis imbalance. However ROS production in this parasite impaired the mitochondrial $\mathrm{Ca}^{2+}$ transport and disrupted the $\mathrm{Ca}^{2+}$ barrier between nuclear envelope and cytosol. Consequently, in response to the extracellular stimulus, the mitochondrion did not accumulate $\mathrm{Ca}^{2+}$ efficiently, leading to accumulation of excess $\mathrm{Ca}^{2+}$ within the nucleus and induction of apoptosis thereafter [22].

Another model of mitochondria-induced apoptosis predicts the rapid loss of the mitochondrial potential by ROS, whereby calcium homeostasis is disturbed after dissipation of $\Delta \Psi \mathrm{m}$. This occurred with intracellular $L$. donovani amastigotes treated with potassium antimony tartrate. Potassium antimony tartrate generated ROS that was primarily concentrated in the macrophage parasitophorous vacuoles. ROS induced the loss of $\Delta \Psi \mathrm{m}$, which finally led to an elevation of $\mathrm{Ca}^{2+}$ concentrations in both parasite and host cells [57].

In most cases, it seems that there is a correlation between ROS formation, calcium imbalance and loss of $\Delta \Psi \mathrm{m}$ (Figure 1, Table 1). However, in other instances loss of $\Delta \Psi \mathrm{m}$ led to apoptosis without the involvement of ROS or the change in $\mathrm{Ca}^{+2}$ concentration. For example, neither ROS nor $\mathrm{Ca}^{2+}$ ions were involved in dissipation of $\Delta \Psi \mathrm{m}$ and apoptosis in L. donovani promastigotes treated with Aloe Vera extracts [28].

To protect themselves against oxidative stress, trypanosomatids possess both non-enzymatic (e.g. glutathione, trypanothione [107], ovothiol A [108]) and enzymatic scavengers. Unlike mammalian cells, trypanosomatids do not encode for the two key antioxidant enzymes catalase and glutathione peroxidase [109]. However, hydrogen peroxide metabolism is based on the trypanothione peroxidase system working in concert with NADPH and trypanothione; and scavenging of ROS from this system is required for parasite survival and infectivity [110-112]. Superoxide ions are detoxified by superoxide dismutase [113] and ROS from the mitochondrial respiratory chain by ascorbate peroxidase [114]. L. major promastigotes over-expressing ascorbate peroxidase showed enhanced tolerance to apoptosis mediated by oxidative stress [114]. Pteridine reductase (PTR1) has a function in essential pteridine salvage as well as in antifolate resistance [115]. The leishmanial PTR1 has been shown to protect intracellular amastigotes against reactive oxygen and nitrogen intermediates' toxicity, while PTR1-/- null mutants survived less well in macrophages [115]. Furthermore the targeting of this enzyme by a glycosyl dihydropyridine analogue induced apoptosis in L. donovani promastigotes [31] and intracellular amastigotes [116]. Likewise, expression of trypanosome alternative oxidase (TAO) [117] was increased under low-temperature stress; and inhibition of TAO was associated with apoptosis in the bloodstream form [118]. Protection of TAO against cell death was associated with protection from ROS generated by drugs like antrycide in TAO over-expressing transgenic T. brucei [23].

Non-metabolic enzymes have also been shown to protect parasites against oxidative stress. The surface lipophosphoglycan (LPG) of Leishmania [119] was suggested to scavenge oxygen radicals and LPG-deficient mutants were indeed more sensitive to ROS [120]. Moreover the cellular chaperone HSP70 has also been proposed to have a protective role against ROS. HSP70 appeared to be upregulated in Leishmania parasites undergoing heat shock, or in parasites treated with a sublethal dose of menadione, generating superoxide and hydrogen peroxide respectively [121] or with a nitric oxide donor [122]. Transfection of promastigotes with HSP70 caused a heat-inducible increase in resistance to peroxide [121]. The authors suggest that HSP70 upregulation is a mechanism for resisting toxic oxidants [121].

\section{Downstream of mitochondrial changes: the execution of apoptosis}

The events that follow the disruption of $\Delta \Psi \mathrm{m}$ result in protease and nuclease activation, responsible for dismantling the respective cells. The main executors of apoptosis in mammalian cells are a group of cysteine proteases, the caspases [123]. However, in the past few years, accumulating evidence in the literature supports the existence of pathways of caspase-independent 
apoptosis with central players proteases being cathepsins, calpains, granzymes $\mathrm{A}$ and $\mathrm{B}$ and the proteases of the proteasome [124]. Trypanosomatids do not have caspase genes, and therefore they undergo a caspaseindependent apoptosis.

An example of a non-caspase executor of apoptosis involves the proteasomal proteases in L. amazonensis amastigotes (Table 1) treated with *NO donors [125]. Other putative executors of apoptosis are metacaspases (MCAs) (Table 1), i.e. cysteine proteases with similar folds as caspases [126]. The genome of T. brucei possesses five metacaspases (TbMCA1-5) [127], whereas two genes are present in T. cruzi (TcMCA3, TcMCA5) [128], two in L. donovani (LdMC1 and LdMC2) [129] and one in L. major (LmjMCA) [130,131]. These proteases have arginine/lysine proteolytic activity, and are unable to cleave caspase-specific substrates $[129,131,132]$. Heterologous expression of TbMCA4 in yeast caused loss of respiration competence and clonal cell death [127], whereas the L. major metacaspase could replace the endogenous yeast metacaspase YCA1 in apoptosis [131]. The role of metacaspases as executors of apoptosis in trypanosomatids still remains controversial. For example, it has been suggested that the two T. cruzi MCAs might be involved in human seruminduced apoptosis [128], and that over-expression of $L$. donovani MCAs renders the parasites more sensitive to hydrogen-peroxide [129]. While TbMCAs (2, 3 and 5) and the $L$. major metacaspase could play a functional role in key steps of the cell-cycle and division [130,133], their function in trypanosomatid apopotosis awaits confirmation.

Although caspases are not present in the trypanosomatid genomes, many investigators have reported the presence of caspase-like activity assessed by the cleavage of caspase-specific substrates and the inhibitory effect of caspase-specific inhibitory peptides $[15,26,44,46,49-51,68,92,114,134,135]$. This activity was described in Leishmania parasites treated with different drugs [92], hydrogen peroxide [15], inhibitors of protein kinase $C[49,100]$, and in $T$. cruzi epimastigotes treated with human serum [135], as well as stationary phase or nutrient deprived parasites [68]. Therefore it is evident that proteases with little homology, but with overlapping activity to metazoan caspases, may be involved in the execution of apoptosis in trypanosomatids. Indeed, Zangger et al. showed that cleavage of the caspase-specific substrate, a DEVD peptide in a 10 day axenic culture, was inhibited by E-64, an inhibitor of cathepsin-like cysteine proteases [69] that does not inhibit caspases [126]. Moreover the DEVDase activity was not present in a double mutant of the cathepsin L-like cysteine CPA/CPB proteases [136], indicating that this activity is likely due to one of the two cysteine proteases [69]. In addition, the intracellular binding of the cell permeate pancaspase inhibitor Z-VAD-FMK, upon heat shock induced apoptosis, was attributed to the binding to the cathepsin B-like cysteine proteinase c (CPC) [137]. CPC was not only shown to bind $\mathrm{z}-\mathrm{VAD}$ but also its knocking out appeared to make parasites survive better when exposed hydrogen peroxide [137], therefore providing strong evidence that at least part of the execution of apoptosis in Leishmania spp. may function via the involvement of CPC [137]. Finally cruzipain, the major cysteine protease of $T$. cruzi, was able to act on caspase substrates at low rates [138]. Overall these data suggest that the caspase substrate activity in trypanosomatids may be stimulated by the lysosomal cathepsin-like proteases (Table 1).

Using protease inhibitors, several investigators have demonstrated that proteases stimulate nucleases to degrade DNA. This was shown with the cysteine protease inhibitor E-64 in staurosporine treated L. donovani promastigotes [100] and with caspase inhibitors in Leishmania and Trypanosoma upon different triggers of cell death $[15,44,46,51,135]$. However, there are many examples of apoptosis, where DNA fragmentation was shown to be insensitive to caspase inhibitors or to caspase-like activity $[22,28,32,47,54,66,69,139,140]$, suggesting that DNA degradation may be under the control of multiple proteases.

Although DNA fragmentation is commonly observed in trypanosomatids undergoing apoptosis, effectors of this pathway have only recently been described (Table 1 ). From the genome data it is known that trypanosomatids do not contain homologues of caspase-activated DNAase (CAD), one of the best characterised nucleases in mammalian apoptosis. In addition to CAD, mammalian cells possess a mitochondrial endonuclease $G$ (EndoG) (Table 1) that translocates to the nucleus during caspase-independent apoptosis [141,142]. EndoG is encoded in the trypanosomatid genome [140,143,144], as a mitochondrial enzyme $[140,144]$ that upon oxidative $[114,143]$ and/or drug induced apoptosis $[32,140,144]$, translocates to the nucleus (Figure 1; $[143,144])$. This enzyme, in the nucleus, forms separate complexes with Flap endonuclease-1 and TatD-like nuclease to generate the degradosome in $L$. donovani promastigotes [140]. Over-expression of this endonuclease strongly promoted apoptotic cell death under oxidant or differentiation-induced stress in Leishmania, while conversely down-regulation of EndoG conferred resistance to oxidative induced cell death in T. brucei [143], indicating that it is an essential effector of apoptosis in trypanosomatids.

During activation of apoptosis, ions and $\mathrm{pH}$ may play an important role in the execution process, affecting 
both nuclease and protease activity. This was demonstrated in camptothecin-treated L. donovani promastigotes, where treatment of the drug was followed by a significant decrease in intracellular $\mathrm{pH}$ and the impairment of the $\mathrm{Na}^{+}-\mathrm{K}^{+}$ATPase pump by oxidative stress [51]. The reduction of the $\mathrm{K}^{+}$concentration and the $\mathrm{pH}$ change propagated the protease activity (DEVDase) of untreated cytosolic L. donovani extracts [51]. Moreover, a nuclease present within the nuclei of untreated extracts of $L$. donovani that became activated in the presence of $\mathrm{Mg}^{2+}$ and/or $\mathrm{Ca}^{2+}$ ions was strongly repressed at physiological concentrations of $\mathrm{K}^{+}$[51]. The authors suggested that $\mathrm{K}^{+}$efflux from the cells during apoptosis is an important regulator of the nuclease activity [51]. Different ion requirements were observed for the nuclease activity from stationary phase $L$. major parasites that was inhibited by $\mathrm{Zn}^{2+}$ ions, and was not dependent on $\mathrm{Ca}^{+2}$ or $\mathrm{Mg}^{2+}$ ions, although the addition of $\mathrm{Mg}^{2+}$ ions improved this activity [69]. These differences in ion concentrations suggest that more than one nuclease is present in Leishmania spp. that is induced by different apoptosis triggers. In addition the L. infantum EndoG required $\mathrm{Mg}^{2+}, \mathrm{Mn}^{2+}$ or $\mathrm{Co}^{2+}$ ions for optimal activity, whereas moderate $\mathrm{K}^{+}$concentrations $(150 \mathrm{mM})$ or higher $\mathrm{Na}^{+}$concentrations $(300 \mathrm{mM})$ inhibited the enzyme [144]. Therefore, imbalances of intracellular ion concentrations and $\mathrm{pH}$ values during apoptosis in trypanosomatids may trigger the caspase-independent activation of proteases and nucleases to execute cell death.

\section{Apoptosis is associated with deregulation of essential biological processes and protein functions in trypanosomatids}

The induction of apoptosis in mammalian cells is often associated with alterations of essential biological processes. For example the tight coupling of proliferation and cell-cycle control with apoptosis, provides a means by which an organism can regulate cell expansion and is imperative for cellular homeostasis. Hence the deregulation of the cell-cycle may result in apoptosis in mammalian cells (reviewed in $[145,146]$ ). The relationship between cell-cycle control and apoptosis is now becoming evident in trypanosomatids (Table 1). A hint to such a relationship came from experiments, where $T$. brucei parasites were treated with the lectin concanavalin A (ConA). ConA used the major cell-surface glycoprotein as a ligand, and induced both cell-cycle defects [147] and apoptosis [148]. In addition, in apoptotic parasites treated with ConA, there was a differential expression of genes whose homologues are known to be involved in cell-cycle control in mammalian cells, like prohibitin, the trypanosome receptor for activated protein $\mathrm{C}$ (RACK) $[149,150]$ and the homologue of the QM protein (a regulator of the c-jun protooncoprotein) $[149,151]$.
Kinases also provide an important link between cellcycle coordination and apoptosis. This was demonstrated by the inhibition of glycogen synthase-3 short isoform ( $L d G S K-3 \mathrm{~s}$ ) and CRK3 (the CDK1 homologue in Leishmania spp.) (Table 1) [65]. The indirubins, 6-Brindirubin-3'-oxime and 6-Br-5-methylindirubin-3'oxime, that show selectivity against CRK3 and LdGSK-3 s respectively, induced apoptosis in $L$. donovani promastigotes [65]. In mammalian cells, CDK1 was shown to be an essential component of certain forms of apoptosis (reviewed in [146]) and provided the functional link between mitotic arrest and apoptosis [152]. In addition, mammalian GSK-3 had a pro-apoptotic action for the intrinsic signalling pathway by the facilitation of signals that cause disruption of mitochondria [153]. Therefore the above observations suggest that the events downstream of GSK-3 and CDK1 and their respective homologues, might be different in mammalian cells and in trypanosomatids. On the contrary staurosporine (prototypical ATP-competitive kinase inhibitor) and withaferin A (potent protein kinase $C$ inhibitor), known apoptogenic agents for mammalian cells [154-156], also induce apoptosis in $L$. donovani parasites $[49,100]$ implying that inhibition of homologous kinases may induce the execution of apoptosis in both trypanosomatids and mammals.

Evidence exists, that proteins associated with proliferation and cell division may be linked to apoptosis in trypanosomatids, as in higher eukaryotes (Table 1). The knocking down of centrin in L. donovani amastigotes, encoding a cytoskeletal calcium binding protein that regulates cytokinesis in trypanosomatids [74,157], induces apoptotic death [74]. In addition, elongationfactor $1 \alpha,(E F-1 \alpha)$ a protein involved in eukaryotic protein biosynthesis and proliferation [158,159], translocates from the cytoplasm to the nucleus, in apoptotic T. cruzi epimastigotes [160]. The authors suggest that the nuclear translocation may confer a distinct function to this protein and that $T c E F-1 \alpha$ could participate in the regulation of expression of genes involved in the control of cell death in T. cruzi [160]. Nevertheless, for assessing an active role of TcEF-1 $\alpha$ in apoptosis, as occurs with the mammalian homologue $[161,162]$ further investigations are required.

Among the genes that have been implicated in the protection against apoptosis are the Silence Information Regulator 2 (Sir2) genes [163]. Homologues of the proteins are classified as NAD dependent deacetylases [164]. Sir2 proteins are hypothesized to play a key role in an organism's response to stresses (such as heat or starvation) and to be responsible for the life-extending effects of calorie restriction mediated by decreased cAMP and thus lowered protein kinase A signalling [164]. L. infantum amastigotes over-expressing the Sir2 
homologue, showed a striking increase in the survival rate due to an inherent resistance to apoptosis [165]. Furthermore, sirtinol, a commercially available inhibitor of SIR2 deacetylases, significantly inhibited the in vitro proliferation of $L$. infantum axenic amastigotes in a dose-dependent manner and induced apoptosis [166]. Promastigotes that over-expressed the gene also showed an increase in viability under starvation conditions [165]. Taking into account the above observations, it is tempting to speculate that Leishmania SIR2 can participate among other factors in the control of cell death (Table 1), and can interact with cellular factors necessary for the cell death machinery [167].

Other genes essential for parasite viability whose inhibition leads to apoptosis in trypanosomatids are topoisomerases (Table 1). Topoisomerases are enzymes that use DNA strand scission, manipulation and rejoining activities to deal with DNA torsional stress, which makes them potential targets for treating parasitic diseases. As topoisomearases are involved in replication, transcription, chromosomal condensation and segregation, inhibitors of these enzymes are expected to interfere with these functions and to have a drastic inhibitory effect on the growth of trypanosomatid parasites [168-172]. The topoisomerase inhibitors berberine [47], camptothecin [51,52], dihydrobetulinic acid [173], baicalein [140], Hoechst 33342 [174], novobiocin [56], pentamidine, doxorubicin [55] luteolin, and diospyrin [38] induce apoptosis, thus providing support that there is a direct correlation between topoisomerase inhibition and apoptosis. The best studied example of apoptosis described in the previous sections has been obtained with camptothecin [51,52], a well characterised topoisomearse IB inhibitor (reviewed in [175]).

The trypanosomatid microtubule cytoskeleton has also been shown to be associated with apoptosis when deregulated. In this respect, agents that interfere with microtubule dynamics (Table 1) including taxol [176] and certain alkaloids [45] induce apoptosis in trypanosomatids. In mammalian cells, the link between microtubules, microtubule interfering agents and apoptosis is mainly associated with modifications of biological processes ( $\mathrm{M}$ phase arrest) and signalling pathways (mitotic spindle assembly checkpoint activation, Bcl-2 phosphorylation, c-Jun NH2-terminal kinase activation) which ultimately lead to the accumulation of signals required for the engagement to cell death (reviewed in [177]). As trypanosomatids lack many of the signalling and effector molecules that regulate apoptosis and key cell-cycle checkpoints (reviewed in [178]), the pathways leading to apoptosis-like death upon exposure to microtubule interfering agents are most likely to be different. A possible mechanism for the action of these drugs may be associated with disruption of microtubule networks within the mitochondrion [177] or via the direct opening of the permeability transition pore [179].

Apart from deregulation of the cytoskeleton, apoptosis is induced by the inhibition of active nuclear transport [180] (Table 1). Ran-GTPase, a small GTPase that was first discovered to be essential in nucleocytoplasmic transport, is now known to regulate a variety of processes such as mitotic spindle assembly, nuclear envelope assembly, cell-cycle progression and the mitotic checkpoint in mammalian cells [181-184]. In T. brucei, RNAi-mediated gene silencing of Ran and of several of its partners RanBP1, CAS, and NTF2 -the latter having a function solely in nucleocytoplasmic transportinduced apoptosis [180], therefore indicating that impairment of this transport is an intrinsic signal for triggering apoptosis in trypanosomatids [180]. This was later confirmed in mammalian cells by Wong et al. who found that active disruption of nuclear trafficking was an important part for promoting apoptosis before the wholesale breakdown of the nuclear envelope and mixing of the cytosolic and nuclear compartments [185].

\section{The Spliced Leader RNA silencing pathway: a novel player in endoplasmic reticulum stress induced apoptosis}

Accumulation of unfolded proteins in the lumen of the endoplasmic reticulum (ER) results in changes of $\mathrm{Ca}^{2+}$ homeostasis, inhibition of glycosylation, oxidative stress and exposure to reducing agents [186]. This induces a coordinated adaptive program called the unfolded protein response (UPR). The UPR alleviates stress by upregulating protein folding and ER associated protein degradation (ERAD) and by inhibiting protein synthesis [186]. However, when protein misfolding is persistent or excessive, ER stress triggers cell death, typically apoptosis [187]. Several mechanisms have been proposed for linking the distressed ER to cell death in Metazoa including direct activation of proteases, kinases, transcription factors, and Bcl-2 family modulators $[186,187]$.

Trypanosomes lack factors that induce UPR, however upon ER stress, transcriptome changes occur in the procyclic form of $T$. brucei, primarily via differential mRNA stabilisation, that are similar to those induced by conventional UPR in metazoans and yeast [93]. The ER stress response triggered by the presence of the reducing agent dithiothreitol (DTT), induced the shutting off of Spliced Leader (SL) RNA transcription by perturbing the binding of the transcription factor tSNAP42 to the SL RNA promoter (Figure 2; [188]), leading to Spliced Leader RNA silencing (SLS). The SLS pathway was also induced by other stresses such as those derived from differences in $\mathrm{pH}$ or silencing of relevant proteins such as the signal-recognition particle receptor [188], SEC63 


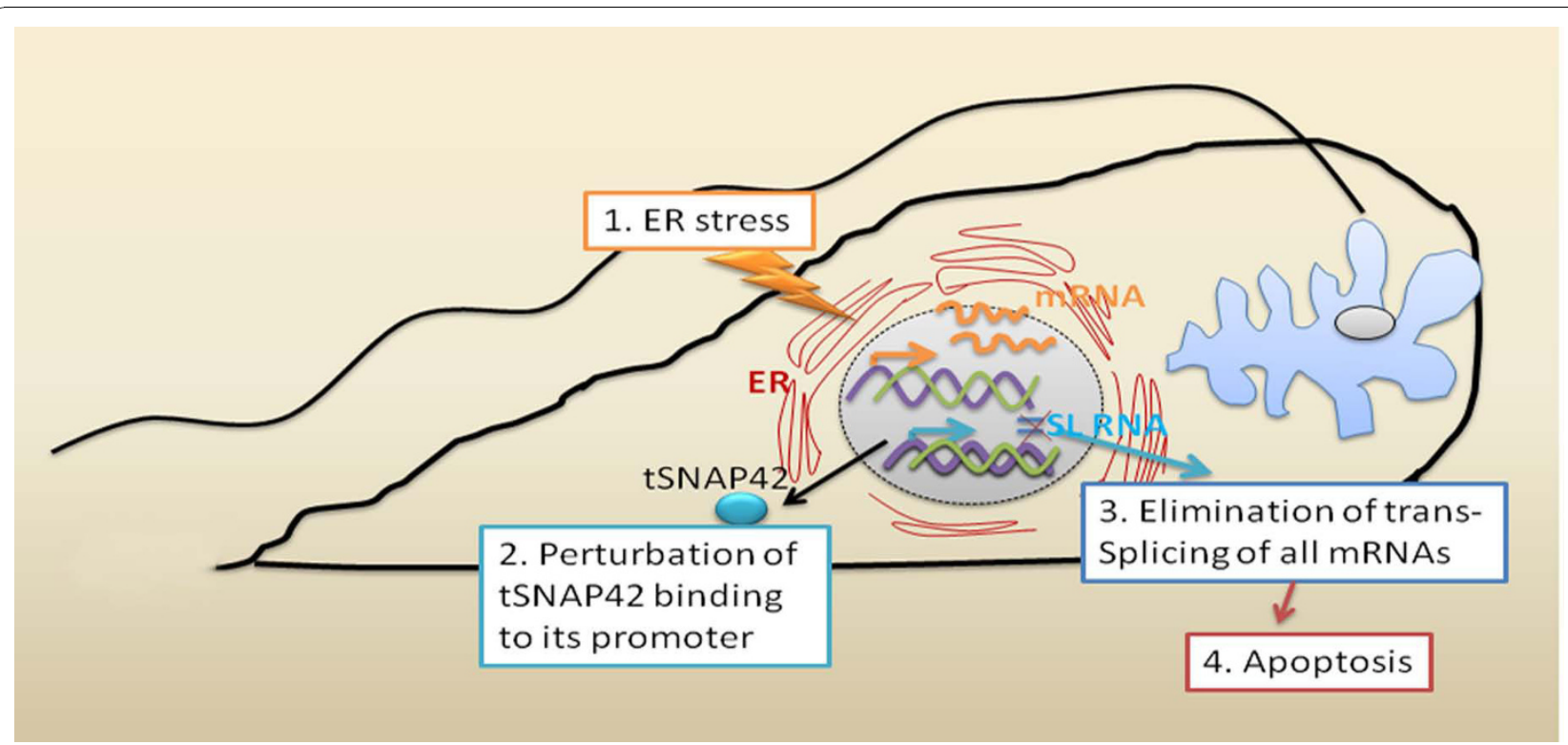

Figure 2 Representation of the ER stress induced Spliced Leader RNA Silencing pathway leading apoptosis in T. brucei. Trypanosomatid parasites share a gene expression mode which differs greatly from that of their human and insect hosts. In these unicellular eukaryotes, protein coding genes are transcribed polycistronically and individual mRNAs are processed from precursors by spliced leader (SL) trans-splicing and polyadenylation. In trans-splicing, the SL RNA is consumed through a transfer of its $5^{\prime}$-terminal part to the $5^{\prime}$-end of mRNAs. Since all mRNAs are trans-spliced, the parasites depend on strong and continuous SL RNA synthesis mediated by RNA polymerase II and transcription factors like tSNAP42. Upon prolonged ER stress (1. ER stress), the binding of tSNAP42 to its cognate promoter, the promoter element of the Spliced Leader RNA (SL RNA) is perturbed (2. Perturbation of tSNAP42 binding to its promoter). This leads to the shutting off of SL RNA transcription and the elimination of trans-splicing of all mRNAs (3. Elimination of trans-splicing of all mRNAs). The SL RNA silencing pathway finally induces apoptosis (4. Apoptosis).

(a protein participating in protein translocation across the ER membrane) or SEC61 (the translocation channel) [93]. The SLS triggered a form of cell death in the parasite, reminiscent of apoptosis (Figure 2), having outcomes like, exposition of phosphatidylserine in the outer leaflet of the plasma membrane, cytoplasmic $\left[\mathrm{Ca}^{2+}\right]$ elevation, reduction in $\Delta \Psi \mathrm{m}$ and ROS formation, as well as ATG8-YFP puncta, indicating the induction of autophagy [93]. The authors proposed that the SLS serves as a unique death pathway, replacing caspase-mediated apoptosis observed in higher eukaryotes [93]. This mechanism of cell death has only been demonstrated in T. brucei, but homologues of the transcription factors that regulate SL transcription are also present in the other trypanosomatids [189] thus making it a possible trypanosomatid-specific apoptosis pathway.

\section{Conclusions}

Trypanosomatids appear to possess an endogenous basic machinery that drives the cells to die in a regulated manner. These unicellular organisms encode homologues of metazoan proteins that control the cell-cycle and cell differentiation, including proto-oncogenes, cyclin and cyclin-dependent kinases, that when deregulated result in mitotic catastrophes and apoptosis [190].
However, trypanosomatids lack the classical metazoan effectors of apoptosis (the typical death receptors, caspases, Bcl-2 family members and p53). Although the nature of the pathways that result in the execution of apoptosis may not exactly recapitulate that of mammalian systems, they represent a simple and valuable model which will assist in the future understanding of the complex connections between apoptotic and nonapoptotic mammalian cell death pathways.

In addition to a better understanding of the evolution of the molecular mechanisms of apoptosis, the physiological relevance of this process in these unicellular organisms has attracted much attention. A possible role of apoptosis in the biology of trypanosomatids would be to control parasite numbers in response to limited resources, or within the host for the perpetuation of the infection [191]. It could also be a useful mechanism to avoid an inflammatory response leading to killing of the entire parasite population $[69,92]$. Apoptosis of Leishmania spp. allows the silencing in human PMNs enabling the intracellular survival of non-apoptotic parasites [192]. In addition, the regulation of apoptosis could allow a stringent coupling of appropriate cell differentiation with cell survival [193]. Furthermore, another possible role of apoptosis in 
these parasites would be the maintenance of clonality and assurance of propagation only of the cells fit to transmit the disease [194].

Finally our ability to unravel the pathways important for apoptosis in these protozoa and to predict the consequences of altering specific components of the larger network will provide us with tools to develop novel treatments for combating the devastating diseases caused by these parasites.

\section{Additional material}

Additional file 1: Table S1 -Inducers, cellular responses and markers of apoptosis in trypansomatids. The table lists known triggers/inducers of apoptosis in trypanosomatid species, as well as the parasites' cellular responses to the above triggers, and markers of apoptosis.

\section{List of abbreviations}

ATG: AuTophaGy; Bad: BCIX /BCL2 associated death promoter homolog: Bax: BCl-2-associated $\times$ protein; $\mathrm{BCl}-2$ : B-cell lymphoma 2; BCl-XL: BCL2L protein: long form of $\mathrm{BCl}-\mathrm{x}$; Bid: $\mathrm{BH} 3$ interacting domain death agonist; $\mathrm{CAS}$ : CAS: cellular apoptosis susceptibility; CPA: cysteine peptidase A; CPB: cysteine peptidase $B ; C P C$ : cysteine peptidase $C ; C R K 3$ : $C d c 2 p$ related protein kinase 3; DR: death receptor; EF-1 $\alpha$ : elongation factor 1 alpha; EndoG: endonuclease G; Hrk: activator of apoptosis harakiri; HSP: heat shock protein; ROS: reactive oxygen species; MMP: permeabilisaton of mitochondrial membranes; NGF-IB: Nerve growth factor-IB; *NO: nitric oxide; NTF-2: nuclear factor 2; PMN: human polymorphonuclear leucocytes; RACK: receptor for activated C-kinase; Ran: RAs-related Nuclear protein; RanBP1: Ran binding protein 1; RNAi: RNA interference; TNF: Tumour Necrosis Factor; UPR: unfolded protein response; YFP: yellow fluorescent protein; Z-VAD-FMK: carbobenzoxy-valyl-alanyl-aspartyl-[O-methyl]-fluoromethylketone; $\triangle \Psi \mathrm{m}$ : mitochondrial membrane potential.

\section{Acknowledgements}

The authors are members of COST (European Cooperation in the field of Scientific and Technical Research) action BM0802 "Life and death of protozoan parasites" and appreciate support from this action. DS and KS acknowledge financial support from Hellenic Pasteur Institute. AJ acknowledges financial support from the Ministerio de Educación y Ciencia, Spain (grant SAF 2006-12713-CO2-O2). NF acknowledges financial support from FNRS (grants $N^{\circ} 3100 A 0-116665 / 1$ ) the Novartis Foundation, the Dr Rub and the Swiss Secretariat for Education and Research in the framework of the COST Action BM0802.

\section{Author details \\ 'Laboratory of Molecular Parasitology, Department of Microbiology, Hellenic Pasteur Institute, 127 Bas. Sofias Ave., 11521 Athens, Greece. ${ }^{2}$ Interfaculty Institute for Biochemistry (IFIB), University of Tübingen, Tübingen, Germany. ${ }^{3}$ Departamento de Bioquímica y Biología Molecular, Campus Universitario, Universidad de Alcalá, 28871 Alcalá de Henares, Madrid, Spain. ${ }^{4}$ Department of Clinical Bacteriology, Parasitology, Zoonoses and Geographical Medicine, Faculty of Medicine, University of Crete, Heraklion, Greece. ${ }^{5}$ University Montpellier 1, UFR Médecine, Laboratoire de Parasitologie-Mycologie, 163 rue Auguste Broussonet, F-34090 Montpellier, France. ${ }^{6}$ Department of Biochemistry, 155 Chemin des Boveresses, University of Lausanne, Epalinges $\mathrm{CH}-1066$, Switzerland.}

\section{Authors' contributions}

DS participated in the conception, design, acquisition and interpretation of data and coordination as well as to draft the manuscript. KS participated in the design, conception, acquisition and interpretation of data, and helped to draft the manuscript. MD, AJR, ES, PB NF have participated in the acquisition and interpretation of data, and have participated in drafting and revising the manuscript. All authors read and approved the final manuscript.

\section{Competing interests}

The authors declare that they have no competing interests.

Received: 1 July 2010 Accepted: 17 November 2010

Published: 17 November 2010

\section{References}

1. Lockshin RA, Facey CO, Zakeri Z: Cell death in the heart. Cardiol Clin 2001, 19:1-11.

2. Lockshin RA, Williams CM: Programmed Cell Death-I. Cytology of Degeneration in the Intersegmental Muscles of the Pernyi Silkmoth. J Insect Physiol 1965, 11:123-133.

3. Kroemer G, Galluzzi L, Vandenabeele P, Abrams J, Alnemri ES, Baehrecke EH, Blagosklonny MV, El-Deiry WS, Golstein P, Green DR, et al: Classification of cell death: recommendations of the Nomenclature Committee on Cell Death 2009. Cell Death Differ 2009, 16:3-11.

4. Kerr JF, Wyllie AH, Currie AR: Apoptosis: a basic biological phenomenon with wide-ranging implications in tissue kinetics. Br J Cancer 1972, 26:239-257.

5. Levine B, Klionsky DJ: Development by self-digestion: molecular mechanisms and biological functions of autophagy. Dev Cell 2004, 6:463-477.

6. Movassagh M, Foo RS: Simplified apoptotic cascades. Heart Fail Rev 2008, 13:111-119.

7. Zhao Y, Li R, Xia W, Neuzil J, Lu Y, Zhang H, Zhao X, Zhang X, Sun C, Wu K. Bid integrates intrinsic and extrinsic signaling in apoptosis induced by alpha-tocopheryl succinate in human gastric carcinoma cells. Cancer Lett 2010, 288:42-49.

8. Stuart K, Brun R, Croft S, Fairlamb A, Gurtler RE, McKerrow J, Reed S, Tarleton R: Kinetoplastids: related protozoan pathogens, different diseases. J Clin Invest 2008, 118:1301-1310.

9. Bruchhaus I, Roeder T, Rennenberg A, Heussler VT: Protozoan parasites: programmed cell death as a mechanism of parasitism. Trends Parasitol 2007, 23:376-383.

10. Menna-Barreto RF, Salomao K, Dantas AP, Santa-Rita RM, Soares MJ, Barbosa HS, de Castro SL: Different cell death pathways induced by drugs in Trypanosoma cruzi: an ultrastructural study. Micron 2009, 40:157-168.

11. Alzate JF, Alvarez-Barrientos A, Gonzalez VM, Jimenez-Ruiz A: Heat-induced programmed cell death in Leishmania infantum is reverted by $\mathrm{Bcl}-\mathrm{X}(\mathrm{L})$ expression. Apoptosis 2006, 11:161-171.

12. Alzate JF, Arias AA, Moreno-Mateos D, Alvarez-Barrientos A, Jimenez-Ruiz A: Mitochondrial superoxide mediates heat-induced apoptotic-like death in Leishmania infantum. Mol Biochem Parasitol 2007, 152:192-202.

13. Moreira ME, Del Portillo HA, Milder RV, Balanco JM, Barcinski MA: Heat shock induction of apoptosis in promastigotes of the unicellular organism Leishmania (Leishmania) amazonensis. J Cell Physiol 1996, 167:305-313.

14. Raina P, Kaur S: Chronic heat-shock treatment driven differentiation induces apoptosis in Leishmania donovani. Mol Cell Biochem 2006 289:83-90

15. Das M, Mukherjee SB, Shaha C: Hydrogen peroxide induces apoptosis-like death in Leishmania donovani promastigotes. J Cell Sci 2001, 114:2461-2469.

16. Deolindo P, Teixeira-Ferreira AS, Damatta RA, Alves EW: I-Amino acid oxidase activity present in fractions of Bothrops jararaca venom is responsible for the induction of programmed cell death in Trypanosoma cruzi. Toxicon 2010, 56:944-955.

17. Figarella K, Uzcategui NL, Beck A, Schoenfeld C, Kubata BK, Lang F, Duszenko M: Prostaglandin-induced programmed cell death in Trypanosoma brucei involves oxidative stress. Cell Death Differ 2006, 13:1802-1814.

18. Holzmuller $P$, Hide $M$, Sereno D, Lemesre JL: Leishmania infantum amastigotes resistant to nitric oxide cytotoxicity: Impact on in vitro parasite developmental cycle and metabolic enzyme activities. Infect Genet Evol 2006, 6:187-197.

19. Irigoin F, Inada NM, Fernandes MP, Piacenza L, Gadelha FR, Vercesi AE, Radi R: Mitochondrial calcium overload triggers complement-dependent superoxide-mediated programmed cell death in Trypanosoma cruzi. Biochem J 2009, 418:595-604.

20. Mukherjee SB, Das M, Sudhandiran G, Shaha C: Increase in cytosolic Ca2+ levels through the activation of non-selective cation channels induced 
by oxidative stress causes mitochondrial depolarization leading to apoptosis-like death in Leishmania donovani promastigotes. J Biol Chem 2002, 277:24717-24727.

21. Piacenza L, Irigoin F, Alvarez MN, Peluffo G, Taylor MC, Kelly JM, Wilkinson SR, Radi R: Mitochondrial superoxide radicals mediate programmed cell death in Trypanosoma cruzi: cytoprotective action of mitochondrial iron superoxide dismutase overexpression. Biochem J 2007, 403:323-334

22. Ridgley $\mathrm{EL}$, Xiong $\mathrm{ZH}$, Ruben $\mathrm{L}$ : Reactive oxygen species activate a Ca2 +-dependent cell death pathway in the unicellular organism Trypanosoma brucei brucei. Biochem J 1999, 340(Pt 1):33-40.

23. Tsuda A, Witola WH, Konnai S, Ohashi K, Onuma M: The effect of TAO expression on PCD-like phenomenon development and drug resistance in Trypanosoma brucei. Parasitol Int 2006, 55:135-142.

24. Alzate JF, Arias A, Mollinedo F, Rico E, de la Iglesia-Vicente J, JimenezRuiz A: Edelfosine induces an apoptotic process in Leishmania infantum that is regulated by the ectopic expression of Bcl-XL and Hrk. Antimicrob Agents Chemother 2008, 52:3779-3782.

25. Benitez J, Guggeri L, Tomaz I, Pessoa JC, Moreno V, Lorenzo J, Aviles FX, Garat B, Gambino D: A novel vanadyl complex with a polypyridyl DNA intercalator as ligand: a potential anti-protozoa and anti-tumor agent. $J$ Inorg Biochem 2009, 103:1386-1394.

26. Das R, Roy A, Dutta N, Majumder HK: Reactive oxygen species and imbalance of calcium homeostasis contributes to curcumin induced programmed cell death in Leishmania donovani. Apoptosis 2008, 13:867-882.

27. De Souza EM, Menna-Barreto R, Araujo-Jorge TC, Kumar A, Hu Q Boykin DW, Soeiro MN: Antiparasitic activity of aromatic diamidines is related to apoptosis-like death in Trypanosoma cruzi. Parasitology 2006, 133:75-79.

28. Dutta A, Bandyopadhyay S, Mandal C, Chatterjee M: Aloe vera leaf exudate induces a caspase-independent cell death in Leishmania donovani promastigotes. J Med Microbiol 2007, 56:629-636.

29. Dutta A, Ghoshal A, Mandal D, Mondal NB, Banerjee S, Sahu NP, Mandal C: Racemoside $A$, an anti-leishmanial, water-soluble, natural steroidal saponin, induces programmed cell death in Leishmania donovani. J Med Microbiol 2007, 56:1196-1204.

30. Jayanarayan KG, Dey CS: Altered expression, polymerisation and cellular distribution of alpha-/beta-tubulins and apoptosis-like cell death in arsenite resistant Leishmania donovani promastigotes. Int J Parasitol 2004, 34:915-925.

31. Kaur J, Singh BK, Tripathi RP, Singh $P$, Singh N: Leishmania donovani: a glycosyl dihydropyridine analogue induces apoptosis like cell death via targeting pteridine reductase 1 in promastigotes. Exp Parasitol 2009 123:258-264.

32. Kumar P, Lodge R, Trudel N, Ouellet M, Ouellette M, Tremblay MJ: Nelfinavir, an HIV-1 protease inhibitor, induces oxidative stressmediated, caspase-independent apoptosis in Leishmania amastigotes. PLoS Negl Trop Dis 2010, 4:e642.

33. Li Q, Zhou Y, Yao C, Ma X, Wang L, Xu W, Wang Z, Qiao Z: Apoptosis caused by $\mathrm{Hsp} 90$ inhibitor geldanamycin in Leishmania donovani during promastigote-to-amastigote transformation stage. Parasitol Res 2009, 105:1539-1548.

34. Mamani-Matsuda M, Rambert J, Malvy D, Lejoly-Boisseau H, Daulouede S, Thiolat D, Coves S, Courtois P, Vincendeau P, Mossalayi MD: Quercetin induces apoptosis of Trypanosoma brucei gambiense and decreases the proinflammatory response of human macrophages. Antimicrob Agents Chemother 2004, 48:924-929.

35. Matsuo AL, Silva LS, Torrecilhas AC, Pascoalino BS, Ramos TC, Rodrigues EG, Schenkman S, Caires AC, Travassos LR: In vitro and in vivo trypanocidal effects of the cyclopalladated compound $7 \mathrm{a}$, a drug candidate for treatment of Chagas' disease. Antimicrob Agents Chemother 2010, 54:3318-3325.

36. Menna-Barreto RF, Laranja GA, Silva MC, Coelho MG, Paes MC, Oliveira MM, de Castro SL: Anti-Trypanosoma cruzi activity of Pterodon pubescens seed oil: geranylgeraniol as the major bioactive component. Parasitol Res 2008, 103:111-117.

37. Mittra B, Saha A, Chowdhury AR, Pal C, Mandal S, Mukhopadhyay S, Bandyopadhyay S, Majumder HK: Luteolin, an abundant dietary component is a potent anti-leishmanial agent that acts by inducing topoisomerase II-mediated kinetoplast DNA cleavage leading to apoptosis. Mol Med 2000, 6:527-541.

38. Mukherjee P, Majee SB, Ghosh S, Hazra B: Apoptosis-like death in Leishmania donovani promastigotes induced by diospyrin and its ethanolamine derivative. Int J Antimicrob Agents 2009, 34:596-601.

39. Neto RL, Sousa LM, Dias CS, Filho JM, Oliveira MR, Figueiredo RC: Morphological and physiological changes in Leishmania promastigotes induced by yangambin, a lignan obtained from Ocotea duckei. Exp Parasitol 2010

40. Nguewa PA, Fuertes MA, Cepeda V, Iborra S, Carrion J, Valladares B, Alonso C, Perez JM: Pentamidine is an antiparasitic and apoptotic drug that selectively modifies ubiquitin. Chem Biodivers 2005, 2:1387-1400

41. Nguewa PA, Fuertes MA, Iborra S, Najajreh Y, Gibson D, Martinez E, Alonso C, Perez JM: Water soluble cationic trans-platinum complexes which induce programmed cell death in the protozoan parasite Leishmania infantum. J Inorg Biochem 2005, 99:727-736.

42. Nkemngu NJ, Rosenkranz V, Wink M, Steverding D: Antitrypanosomal activities of proteasome inhibitors. Antimicrob Agents Chemother 2002, 46:2038-2040.

43. Pardo Andreu GL, Inada NM, Pellon RF, Docampo ML, Fascio ML, D'Accorso NB, Vercesi AE: In vitro effect of a new cinnamic acid derivative against the epimastigote form of Trypanosoma cruzi. Arzneimittelforschung 2009, 59:207-211.

44. Paris C, Loiseau PM, Bories C, Breard J: Miltefosine induces apoptosis-like death in Leishmania donovani promastigotes. Antimicrob Agents Chemother 2004, 48:852-859.

45. Rosenkranz $\mathrm{V}$, Wink M: Alkaloids induce programmed cell death in bloodstream forms of trypanosomes (Trypanosoma b. brucei). Molecules 2008, 13:2462-2473.

46. Roy A, Ganguly A, BoseDasgupta S, Das BB, Pal C, Jaisankar P, Majumder HK: Mitochondria-dependent reactive oxygen species-mediated programmed cell death induced by 3,3'-diindolylmethane through inhibition of FOF1-ATP synthase in unicellular protozoan parasite Leishmania donovani. Mol Pharmacol 2008, 74:1292-1307.

47. Saha P, Sen R, Hariharan C, Kumar D, Das P, Chatterjee M: Berberine chloride causes a caspase-independent, apoptotic-like death in Leishmania donovani promastigotes. Free Radic Res 2009, 1-10.

48. Sarkar A, Sen R, Saha P, Ganguly S, Mandal G, Chatterjee M: An ethanolic extract of leaves of Piper betle (Paan) Linn mediates its antileishmanial activity via apoptosis. Parasitol Res 2008, 102:1249-1255.

49. Sen N, Banerjee B, Das BB, Ganguly A, Sen T, Pramanik S, Mukhopadhyay S, Majumder HK: Apoptosis is induced in leishmanial cells by a novel protein kinase inhibitor withaferin $A$ and is facilitated by apoptotic topoisomerase I-DNA complex. Cell Death Differ 2007, 14:358-367.

50. Sen N, Das BB, Ganguly A, Banerjee B, Sen T, Majumder HK: Leishmania donovani: intracellular ATP level regulates apoptosis-like death in luteolin induced dyskinetoplastid cells. Exp Parasitol 2006, 114:204-214.

51. Sen N, Das BB, Ganguly A, Mukherjee T, Bandyopadhyay S, Majumder HK: Camptothecin-induced imbalance in intracellular cation homeostasis regulates programmed cell death in unicellular hemoflagellate Leishmania donovani. J Biol Chem 2004, 279:52366-52375.

52. Sen N, Das BB, Ganguly A, Mukherjee T, Tripathi G, Bandyopadhyay S, Rakshit S, Sen T, Majumder HK: Camptothecin induced mitochondrial dysfunction leading to programmed cell death in unicellular hemoflagellate Leishmania donovani. Cell Death Differ 2004, 11:924-936.

53. Sen R, Bandyopadhyay S, Dutta A, Mandal G, Ganguly S, Saha P, Chatterjee M: Artemisinin triggers induction of cell-cycle arrest and apoptosis in Leishmania donovani promastigotes. J Med Microbiol 2007, 56:1213-1218.

54. Sereno D, Holzmuller P, Mangot I, Cuny G, Ouaissi A, Lemesre JL: Antimonial-mediated DNA fragmentation in Leishmania infantum amastigotes. Antimicrob Agents Chemother 2001, 45:2064-2069.

55. Singh G, Dey CS: Induction of apoptosis-like cell death by pentamidine and doxorubicin through differential inhibition of topoisomerase II in arsenite-resistant L. donovani. Acta Trop 2007, 103:172-185.

56. Singh G, Jayanarayan KG, Dey CS: Novobiocin induces apoptosis-like cell death in topoisomerase II over-expressing arsenite resistant Leishmania donovani. Mol Biochem Parasitol 2005, 141:57-69.

57. Sudhandiran G, Shaha C: Antimonial-induced increase in intracellular Ca2 + through non-selective cation channels in the host and the parasite is 
responsible for apoptosis of intracellular Leishmania donovani amastigotes. J Biol Chem 2003, 278:25120-25132.

58. Tavares J, Ouaissi A, Kong Thoo Lin P, Loureiro I, Kaur S, Roy N, Cordeiro-daSilva A: Bisnaphthalimidopropyl derivatives as inhibitors of Leishmania SIR2 related protein 1. ChemMedChem 2010, 5:140-147.

59. Tavares J, Ouaissi A, Lin PK, Tomas A, Cordeiro-da-Silva A: Differential effects of polyamine derivative compounds against Leishmania infantum promastigotes and axenic amastigotes. Int J Parasitol 2005, 35:637-646.

60. Urbina JA: Mechanisms of action of lysophospholipid analogues against trypanosomatid parasites. Trans R Soc Trop Med Hyg 2006, 100(Suppl 1): S9-S16.

61. Uzcategui NL, Carmona-Gutierrez D, Denninger V, Schoenfeld C, Lang F, Figarella K, Duszenko M: Antiproliferative effect of dihydroxyacetone on Trypanosoma brucei bloodstream forms: cell cycle progression, subcellular alterations, and cell death. Antimicrob Agents Chemother 2007, 51:3960-3968.

62. Uzcategui NL, Denninger V, Merkel P, Schoenfeld C, Figarella K, Duszenko M: Dihydroxyacetone induced autophagy in African trypanosomes. Autophagy 2007, 3:626-629.

63. Verma NK, Dey CS: Possible mechanism of miltefosine-mediated death of Leishmania donovani. Antimicrob Agents Chemother 2004, 48:3010-3015.

64. Verma NK, Singh G, Dey CS: Miltefosine induces apoptosis in arseniteresistant Leishmania donovani promastigotes through mitochondrial dysfunction. Exp Parasitol 2007, 116:1-13.

65. Xingi E, Smirlis D, Myrianthopoulos V, Magiatis P, Grant KM, Meijer L, Mikros E, Skaltsounis AL, Soteriadou K: 6-Br-5methylindirubin-3'oxime (5Me-6-BIO) targeting the leishmanial glycogen synthase kinase-3 (GSK-3) short form affects cell-cycle progression and induces apoptosis-like death: exploitation of GSK-3 for treating leishmaniasis. Int J Parasitol 2009, 39:1289-1303.

66. Figarella K, Rawer M, Uzcategui NL, Kubata BK, Lauber K, Madeo F, Wesselborg S, Duszenko M: Prostaglandin D2 induces programmed cell death in Trypanosoma brucei bloodstream form. Cell Death Differ 2005, 12:335-346.

67. Alvarez VE, Kosec G, Sant'Anna C, Turk V, Cazzulo JJ, Turk B: Autophagy is involved in nutritional stress response and differentiation in Trypanosoma cruzi. J Biol Chem 2008, 283:3454-3464.

68. Jimenez V, Paredes R, Sosa MA, Galanti N: Natural programmed cell death in T. cruzi epimastigotes maintained in axenic cultures. J Cell Biochem 2008, 105:688-698

69. Zangger $\mathrm{H}$, Mottram JC, Fasel $\mathrm{N}$ : Cell death in Leishmania induced by stress and differentiation: programmed cell death or necrosis? Cell Death Differ 2002, 9:1126-1139.

70. Kulkarni MM, McMaster WR, Kamysz W, McGwire BS: Antimicrobial peptideinduced apoptotic death of leishmania results from calcium-de pend ent, caspase-independent mitochondrial toxicity. J Biol Chem 2009, 284:15496-15504.

71. Luque-Ortega JR, Cruz LJ, Albericio F, Rivas L: The Antitumoral Depsipeptide IB-01212 Kills Leishmania through an Apoptosis-like Process Involving Intracellular Targets. Mol Pharm 2010

72. Fernandez-Presas AM, Tato P, Becker I, Solano S, Kopitin N, Berzunza M, Willms K, Hernandez J, Molinari JL: Specific antibodies induce apoptosis in Trypanosoma cruzi epimastigotes. Parasitol Res 2010, 106:1327-37.

73. Ameisen JC, Idziorek T, Billaut-Mulot O, Loyens M, Tissier JP, Potentier A, Ouaissi A: Apoptosis in a unicellular eukaryote (Trypanosoma cruzi): implications for the evolutionary origin and role of programmed cell death in the control of cell proliferation, differentiation and survival. Cell Death Differ 1995, 2:285-300.

74. Selvapandiyan A, Debrabant A, Duncan R, Muller J, Salotra P, Sreenivas G, Salisbury JL, Nakhasi HL: Centrin gene disruption impairs stage-specific basal body duplication and cell cycle progression in Leishmania. J Biol Chem 2004, 279:25703-25710.

75. Deponte M: Programmed cell death in protists. Biochim Biophys Acta 2008, 1783:1396-1405.

76. Duszenko M, Figarella K, Macleod ET, Welburn SC: Death of a trypanosome: a selfish altruism. Trends Parasitol 2006, 22:536-542.

77. Herman M, Gillies S, Michels PA, Rigden DJ: Autophagy and related processes in trypanosomatids: insights from genomic and bioinformatic analyses. Autophagy 2006, 2:107-118.
78. Kiel JA: Autophagy in unicellular eukaryotes. Philos Trans $R$ Soc Lond B Biol Sci 2010, 365:819-830.

79. Rigden DJ, Herman M, Gillies S, Michels PA: Implications of a genomic search for autophagy-related genes in trypanosomatids. Biochem Soc Trans 2005, 33:972-974.

80. Alvarez VE, Kosec G, Sant Anna C, Turk V, Cazzulo JJ, Turk B: Blocking autophagy to prevent parasite differentiation: a possible new strategy for fighting parasitic infections? Autophagy 2008, 4:361-363.

81. Besteiro S, Williams RA, Morrison LS, Coombs GH, Mottram JC: Endosome sorting and autophagy are essential for differentiation and virulence of Leishmania major. J Biol Chem 2006, 281:11384-11396.

82. Besteiro S, Williams RA, Coombs GH, Mottram JC: Protein turnover and differentiation in Leishmania. Int J Parasitol 2007, 37:1063-1075.

83. Menna-Barreto RF, Correa JR, Cascabulho CM, Fernandes MC, Pinto AV Soares MJ, De Castro SL: Naphthoimidazoles promote different death phenotypes in Trypanosoma cruzi. Parasitology 2009, 136:499-510.

84. Menna-Barreto RF, Correa JR, Pinto AV, Soares MJ, de Castro SL: Mitochondrial disruption and DNA fragmentation in Trypanosoma cruzi induced by naphthoimidazoles synthesized from beta-lapachone. Parasitol Res 2007, 101:895-905.

85. Merkel P, Beck A, Muhammad K, Ali SA, Schonfeld C, Voelter W, Duszenko M: Spermine isolated and identified as the major trypanocidal compound from the snake venom of Eristocophis macmahoni causes autophagy in Trypanosoma brucei. Toxicon 2007, 50:457-469.

86. Bera A, Singh S, Nagaraj R, Vaidya T: Induction of autophagic cell death in Leishmania donovani by antimicrobial peptides. Mol Biochem Parasitol 2003, 127:23-35.

87. Delgado M, Anderson P, Garcia-Salcedo JA, Caro M, Gonzalez-Rey E: Neuropeptides kill African trypanosomes by targeting intracellular compartments and inducing autophagic-like cell death. Cell Death Differ 2009, 16:406-416.

88. McGwire BS, Kulkarni MM: Interactions of antimicrobial peptides with Leishmania and trypanosomes and their functional role in host parasitism. Exp Parasitol 2010, 126:397-405.

89. Keeble JA, Gilmore AP: Apoptosis commitment-translating survival signals into decisions on mitochondria. Cell Res 2007, 17:976-984.

90. Gottlieb E, Armour SM, Harris MH, Thompson CB: Mitochondrial membrane potential regulates matrix configuration and cytochrome $c$ release during apoptosis. Cell Death Differ 2003, 10:709-717.

91. Ly JD, Grubb DR, Lawen A: The mitochondrial membrane potential (deltapsi(m)) in apoptosis; an update. Apoptosis 2003, 8:115-128.

92. Lee N, Bertholet S, Debrabant A, Muller J, Duncan R, Nakhasi HL: Programmed cell death in the unicellular protozoan parasite Leishmania. Cell Death Differ 2002, 9:53-64.

93. Goldshmidt H, Matas D, Kabi A, Carmi S, Hope R, Michaeli S: Persistent ER stress induces the spliced leader RNA silencing pathway (SLS), leading to programmed cell death in Trypanosoma brucei. PLOS Pathog 2010, 6 : e1000731.

94. Shaha C: Apoptosis in Leishmania species \& its relevance to disease pathogenesis. Indian J Med Res 2006, 123:233-244.

95. Luque-Ortega JR, Reuther P, Rivas L, Dardonville C: New benzophenonederived bisphosphonium salts as leishmanicidal leads targeting mitochondria through inhibition of respiratory complex II. J Med Chem 2010, 53:1788-1798.

96. Mehta A, Shaha C: Apoptotic death in Leishmania donovani promastigotes in response to respiratory chain inhibition: complex II inhibition results in increased pentamidine cytotoxicity. J Biol Chem 2004, 279:11798-11813.

97. Gross A, McDonnell JM, Korsmeyer SJ: BCL-2 family members and the mitochondria in apoptosis. Genes Dev 1999, 13:1899-1911.

98. Hsu YT, Wolter KG, Youle RJ: Cytosol-to-membrane redistribution of Bax and BCl-X(L) during apoptosis. Proc Natl Acad Sci USA 1997, 94:3668-3672.

99. Hsu YT, Youle RJ: Nonionic detergents induce dimerization among members of the Bcl-2 family. J Biol Chem 1997, 272:13829-13834.

100. Arnoult D, Akarid K, Grodet A, Petit PX, Estaquier J, Ameisen JC: On the evolution of programmed cell death: apoptosis of the unicellular eukaryote Leishmania major involves cysteine proteinase activation and mitochondrion permeabilization. Cell Death Differ 2002, 9:65-81.

101. Esseiva AC, Chanez AL, Bochud-Allemann N, Martinou JC, Hemphill A, Schneider A: Temporal dissection of Bax-induced events leading to 
fission of the single mitochondrion in Trypanosoma brucei. EMBO Rep 2004, 5:268-273.

102. Circu ML, Moyer MP, Harrison L, Aw TY: Contribution of glutathione status to oxidant-induced mitochondrial DNA damage in colonic epithelial cells. Free Radic Biol Med 2009, 47:1190-1198.

103. Orrenius S, Zhivotovsky B, Nicotera P: Regulation of cell death: the calcium-apoptosis link. Nat Rev Mol Cell Biol 2003, 4:552-565.

104. Brookes PS, Yoon Y, Robotham JL, Anders MW, Sheu SS: Calcium, ATP, and ROS: a mitochondrial love-hate triangle. Am J Physiol Cell Physiol 2004, 287:C817-833.

105. Camello-Almaraz C, Gomez-Pinilla PJ, Pozo MJ, Camello PJ: Mitochondrial reactive oxygen species and $\mathrm{Ca} 2+$ signaling. Am J Physiol Cell Physiol 2006, 291:C1082-1088.

106. Vercesi AE, Kowaltowski AJ, Oliveira HC, Castilho RF: Mitochondrial Ca2+ transport, permeability transition and oxidative stress in cell death: implications in cardiotoxicity, neurodegeneration and dyslipidemias. Front Biosci 2006, 11:2554-2564.

107. Fairlamb AH, Blackburn P, Ulrich P, Chait BT, Cerami A: Trypanothione: a novel bis(glutathionyl)spermidine cofactor for glutathione reductase in trypanosomatids. Science 1985, 227:1485-1487.

108. Spies HS, Steenkamp DJ: Thiols of intracellular pathogens. Identification of ovothiol A in Leishmania donovani and structural analysis of a novel thiol from Mycobacterium bovis. Eur J Biochem 1994, 224:203-213.

109. Penketh PG, Kennedy WP, Patton CL, Sartorelli AC: Trypanosomatid hydrogen peroxide [corrected] metabolism. FEBS Lett 1987, 221:427-431.

110. Irigoin F, Cibils L, Comini MA, Wilkinson SR, Flohe L, Radi R: Insights into the redox biology of Trypanosoma cruzi: Trypanothione metabolism and oxidant detoxification. Free Radic Biol Med 2008, 45:733-742.

111. Krauth-Siegel LR, Comini MA, Schlecker T: The trypanothione system. Subcell Biochem 2007, 44:231-251.

112. Krieger S, Schwarz W, Ariyanayagam MR, Fairlamb AH, Krauth-Siegel RL, Clayton C: Trypanosomes lacking trypanothione reductase are avirulent and show increased sensitivity to oxidative stress. Mol Microbiol 2000, 35:542-552.

113. Plewes KA, Barr SD, Gedamu L: Iron superoxide dismutases targeted to the glycosomes of Leishmania chagasi are important for survival. Infect Immun 2003, 71:5910-5920.

114. Dolai S, Yadav RK, Pal S, Adak S: Overexpression of mitochondrial Leishmania major ascorbate peroxidase enhances tolerance to oxidative stress-induced programmed cell death and protein damage. Eukaryot Cell 2009, 8:1721-1731.

115. Moreira W, Leblanc E, Ouellette M: The role of reduced pterins in resistance to reactive oxygen and nitrogen intermediates in the protozoan parasite Leishmania. Free Radic Biol Med 2009, 46:367-375.

116. Kaur J, Singh N, Singh BK, Dube A, Tripathi RP, Singh P, Singh N: Leishmania donovani: Oral therapy with glycosyl 1,4-dihydropyridine analogue showing apoptosis like phenotypes targeting pteridine reductase 1 in intracellular amastigotes. Exp Parasitol 2010, 125:310-4.

117. Opperdoes FR, Coombs GH: Metabolism of Leishmania: proven and predicted. Trends Parasitol 2007, 23:149-158.

118. Tsuda A, Witola WH, Ohashi K, Onuma M: Expression of alternative oxidase inhibits programmed cell death-like phenomenon in bloodstream form of Trypanosoma brucei rhodesiense. Parasitol Int 2005, 54:243-251.

119. Chaudhuri G, Chaudhuri M, Pan A, Chang KP: Surface acid proteinase (gp63) of Leishmania mexicana. A metalloenzyme capable of protecting liposome-encapsulated proteins from phagolysosomal degradation by macrophages. J Biol Chem 1989, 264:7483-7489.

120. Spath GF, Garraway LA, Turco SJ, Beverley SM: The role(s) of lipophosphoglycan (LPG) in the establishment of Leishmania major infections in mammalian hosts. Proc Natl Acad Sci USA 2003, 100:9536-9541.

121. Miller MA, McGowan SE, Gantt KR, Champion M, Novick SL, Andersen KA, Bacchi CJ, Yarlett N, Britigan BE, Wilson ME: Inducible resistance to oxidant stress in the protozoan Leishmania chagasi. J Biol Chem 2000, 275:33883-33889.

122. Dea-Ayuela MA, Ordonez-Gutierrez L, Bolas-Fernandez F: Changes in the proteome and infectivity of Leishmania infantum induced by in vitro exposure to a nitric oxide donor. Int J Med Microbiol 2009, 299:221-232.
123. Feinstein-Rotkopf $Y$, Arama $E$ : Can't live without them, can live with them: roles of caspases during vital cellular processes. Apoptosis 2009, 14:980-995.

124. Constantinou C, Papas KA, Constantinou Al: Caspase-independent pathways of programmed cell death: the unraveling of new targets of cancer therapy? Curr Cancer Drug Targets 2009, 9:717-728.

125. Holzmuller P, Sereno D, Cavaleyra M, Mangot I, Daulouede S, Vincendeau P, Lemesre JL: Nitric oxide-mediated proteasome-dependent oligonucleosomal DNA fragmentation in Leishmania amazonensis amastigotes. Infect Immun 2002, 70:3727-3735.

126. Mottram JC, Helms MJ, Coombs GH, Sajid M: Clan CD cysteine peptidases of parasitic protozoa. Trends Parasitol 2003, 19:182-187.

127. Szallies A, Kubata BK, Duszenko M: A metacaspase of Trypanosoma brucei causes loss of respiration competence and clonal death in the yeast Saccharomyces cerevisiae. FEBS Lett 2002, 517:144-150.

128. Kosec G, Alvarez VE, Aguero F, Sanchez D, Dolinar M, Turk B, Turk V, Cazzulo JJ: Metacaspases of Trypanosoma cruzi: possible candidates for programmed cell death mediators. Mol Biochem Parasitol 2006, 145:18-28.

129. Lee N, Gannavaram S, Selvapandiyan A, Debrabant A: Characterization of metacaspases with trypsin-like activity and their putative role in programmed cell death in the protozoan parasite Leishmania. Eukaryot Cell 2007, 6:1745-1757.

130. Ambit A, Fasel N, Coombs GH, Mottram JC: An essential role for the Leishmania major metacaspase in cell cycle progression. Cell Death Differ 2008, 15:113-122.

131. Gonzalez IJ, Desponds C, Schaff C, Mottram JC, Fasel N: Leishmania major metacaspase can replace yeast metacaspase in programmed cell death and has arginine-specific cysteine peptidase activity. Int J Parasitol 2007, 37:161-172.

132. Moss CX, Westrop GD, Juliano L, Coombs GH, Mottram JC: Metacaspase 2 of Trypanosoma brucei is a calcium-dependent cysteine peptidase active without processing. FEBS Lett 2007, 581:5635-5639.

133. Helms MJ, Ambit A, Appleton P, Tetley L, Coombs GH, Mottram JC: Bloodstream form Trypanosoma brucei depend upon multiple metacaspases associated with RAB11-positive endosomes. J Cell Sci 2006, 119:1105-1117.

134. Deolindo P, Teixeira-Ferreira AS, Melo EJ, Arnholdt AC, Souza W, Alves EW, DaMatta RA: Programmed cell death in Trypanosoma cruzi induced by Bothrops jararaca venom. Mem Inst Oswaldo Cruz 2005, 100:33-38.

135. Piacenza L, Peluffo G, Radi R: L-arginine-dependent suppression of apoptosis in Trypanosoma cruzi: contribution of the nitric oxide and polyamine pathways. Proc Natl Acad Sci USA 2001, 98:7301-7306.

136. Mottram JC, Souza AE, Hutchison JE, Carter R, Frame MJ, Coombs GH: Evidence from disruption of the Imcpb gene array of Leishmania mexicana that cysteine proteinases are virulence factors. Proc Natl Acad Sci USA 1996, 93:6008-6013.

137. El-Fadili AK, Zangger $H$, Desponds C, IJ G, Zalila H, Schaff C, Ives A, Masina S, Mottram JC, Fasel N: Cathepsin B-like and cell death in the unicellular human pathogen Leishmania. Cell Death and Disease.

138. Stoka V, Turk B, Schendel SL, Kim TH, Cirman T, Snipas SJ, Ellerby LM, Bredesen D, Freeze $H$, Abrahamson $M$, et al: Lysosomal protease pathways to apoptosis. Cleavage of bid, not pro-caspases, is the most likely route. J Biol Chem 2001, 276:3149-3157.

139. Akarid K, Arnoult D, Micic-Polianski J, Sif J, Estaquier J, Ameisen JC: Leishmania major-mediated prevention of programmed cell death induction in infected macrophages is associated with the repression of mitochondrial release of cytochrome c. J Leukoc Biol 2004, 76:95-103

140. BoseDasgupta S, Das BB, Sengupta S, Ganguly A, Roy A, Dey S, Tripathi G, Dinda B, Majumder HK: The caspase-independent algorithm of programmed cell death in Leishmania induced by baicalein: the role of LdEndoG, LdFEN-1 and LdTatD as a DNA 'degradesome'. Cell Death Differ 2008, 15:1629-1640.

141. Ishihara $Y$, Shimamoto $N$ : Involvement of endonuclease $G$ in nucleosomal DNA fragmentation under sustained endogenous oxidative stress. J Biol Chem 2006, 281:6726-6733.

142. Li LY, Luo X, Wang X: Endonuclease $G$ is an apoptotic DNase when released from mitochondria. Nature 2001, 412:95-99.

143. Gannavaram S, Vedvyas C, Debrabant A: Conservation of the proapoptotic nuclease activity of endonuclease $G$ in unicellular trypanosomatid parasites. J Cell Sci 2008, 121:99-109. 
144. Rico E, Alzate JF, Arias AA, Moreno D, Clos J, Gago F, Moreno I, Dominguez $M$, Jimenez-Ruiz A: Leishmania infantum expresses a mitochondrial nuclease homologous to EndoG that migrates to the nucleus in response to an apoptotic stimulus. Mol Biochem Parasitol 2009, 163:28-38.

145. Clarke PR, Allan LA: Cell-cycle control in the face of damage-a matter of life or death. Trends Cell Biol 2009, 19:89-98.

146. Kasten MM, Giordano A: pRb and the cdks in apoptosis and the cell cycle. Cell Death Differ 1998, 5:132-140.

147. Pearson TW, Beecroft RP, Welburn SC, Ruepp S, Roditi I, Hwa KY, Englund PT, Wells CW, Murphy NB: The major cell surface glycoprotein procyclin is a receptor for induction of a novel form of cell death in African trypanosomes in vitro. Mol Biochem Parasitol 2000, 111:333-349.

148. Welburn SC, Dale C, Ellis D, Beecroft R, Pearson TW: Apoptosis in procyclic Trypanosoma brucei rhodesiense in vitro. Cell Death Differ 1996, 3:229-236

149. Welburn SC, Lillico S, Murphy NB: Programmed cell death in procyclic form Trypanosoma brucei rhodesiense-identification of differentially expressed genes during con A induced death. Mem Inst Oswaldo Cruz 1999, 94:229-234.

150. Welburn SC, Murphy NB: Prohibitin and RACK homologues are upregulated in trypanosomes induced to undergo apoptosis and in naturally occurring terminally differentiated forms. Cell Death Differ 1998, 5:615-622.

151. Lillico SG, Mottram JC, Murphy NB, Welburn SC: Characterisation of the QM gene of Trypanosoma brucei. FEMS Microbiol Lett 2002, 211:123-128.

152. Terrano DT, Upreti M, Chambers TC: Cyclin-dependent kinase 1-mediated $\mathrm{Bcl}-\mathrm{xL} / \mathrm{Bcl}-2$ phosphorylation acts as a functional link coupling mitotic arrest and apoptosis. Mol Cell Biol 2010, 30:640-656.

153. Beurel $E$, Jope RS: The paradoxical pro- and anti-apoptotic actions of GSK3 in the intrinsic and extrinsic apoptosis signaling pathways. Prog Neurobiol 2006, 79:173-189.

154. Antonsson A, Persson JL: Induction of apoptosis by staurosporine involves the inhibition of expression of the major cell cycle proteins at the $\mathrm{G}(2) / \mathrm{m}$ checkpoint accompanied by alterations in Erk and Akt kinase activities. Anticancer Res 2009, 29:2893-2898.

155. Mandal C, Dutta A, Mallick A, Chandra S, Misra L, Sangwan RS: Withaferin A induces apoptosis by activating p38 mitogen-activated protein kinase signaling cascade in leukemic cells of lymphoid and myeloid origin through mitochondrial death cascade. Apoptosis 2008, 13:1450-1464.

156. Park HJ, Rayalam S, Della-Fera MA, Ambati S, Yang JY, Baile CA: Withaferin A induces apoptosis and inhibits adipogenesis in 3T3-L1 adipocytes. Biofactors 2008, 33:137-148.

157. Selvapandiyan A, Kumar P, Morris JC, Salisbury JL, Wang CC, Nakhasi HL: Centrin 1 is required for organelle segregation and cytokinesis in Trypanosoma brucei. Mol Biol Cell 2007, 18:3290-3301.

158. Negrutskii BS, El'skaya AV: Eukaryotic translation elongation factor 1 alpha: structure, expression, functions, and possible role in aminoacyltRNA channeling. Prog Nucleic Acid Res Mol Biol 1998, 60:47-78.

159. Pecorari L, Marin O, Silvestri C, Candini O, Rossi E, Guerzoni C, Cattelani S, Mariani SA, Corradini F, Ferrari-Amorotti G, et al: Elongation Factor 1 alpha interacts with phospho-Akt in breast cancer cells and regulates their proliferation, survival and motility. Mol Cancer 2009, 8:58.

160. Billaut-Mulot O, Fernandez-Gomez R, Loyens M, Ouaissi A: Trypanosoma cruzi elongation factor 1-alpha: nuclear localization in parasites undergoing apoptosis. Gene 1996, 174:19-26.

161. Duttaroy A, Bourbeau D, Wang XL, Wang E: Apoptosis rate can be accelerated or decelerated by overexpression or reduction of the level of elongation factor-1 alpha. Exp Cell Res 1998, 238:168-176.

162. Talapatra S, Wagner JD, Thompson CB: Elongation factor-1 alpha is a selective regulator of growth factor withdrawal and ER stress-induced apoptosis. Cell Death Differ 2002, 9:856-861.

163. Cheng HL, Mostoslavsky R, Saito S, Manis JP, Gu Y, Patel P, Bronson R, Appella E, Alt FW, Chua KF: Developmental defects and p53 hyperacetylation in Sir2 homolog (SIRT1)-deficient mice. Proc Natl Acad Sci USA 2003, 100:10794-10799.

164. Sinclair DA, Lin SJ, Guarente L: Life-span extension in yeast. Science 2006, 312:195-197, author reply 195-197.

165. Vergnes B, Sereno D, Madjidian-Sereno N, Lemesre JL, Ouaissi A: Cytoplasmic SIR2 homologue overexpression promotes survival of
Leishmania parasites by preventing programmed cell death. Gene 2002 296:139-150.

166. Vergnes B, Vanhille L, Ouaissi A, Sereno D: Stage-specific antileishmanial activity of an inhibitor of SIR2 histone deacetylase. Acta Trop 2005, 94:107-115.

167. Ouaissi A: Apoptosis-like death in trypanosomatids: search for putative pathways and genes involved. Kinetoplastid Biol Dis 2003, 2:5.

168. Balana-Fouce R, Redondo CM, Perez-Pertejo Y, Diaz-Gonzalez R, Reguera RM: Targeting atypical trypanosomatid DNA topoisomerase I. Drug Discov Today 2006, 11:733-740

169. Das BB, Sen N, Dasgupta SB, Ganguly A, Das R, Majumder HK: Topoisomerase research of kinetoplastid parasite Leishmania, with special reference to development of therapeutics. Indian J Med Res 2006, 123:221-232.

170. De Sousa JM, Lareau SM, Pearson RD, Carvalho EM, Mann BJ, Jeronimo SM: Characterization of Leishmania chagasi DNA topoisomerase II: a potential chemotherapeutic target. Scand J Infect Dis 2003, 35:826-829.

171. Deterding A, Dungey FA, Thompson KA, Steverding D: Anti-trypanosomal activities of DNA topoisomerase inhibitors. Acta Trop 2005, 93:311-316.

172. Douc-Rasy S, Riou JF, Ahomadegbe JC, Riou G: ATP-independent DNA topoisomerase II as potential drug target in trypanosomes. Biol Cell 1988, 64:145-156.

173. Chowdhury AR, Mandal S, Goswami A, Ghosh M, Mandal L, Chakraborty D, Ganguly A, Tripathi G, Mukhopadhyay S, Bandyopadhyay S, Majumder HK: Dihydrobetulinic acid induces apoptosis in Leishmania donovani by targeting DNA topoisomerase I and II: implications in antileishmanial therapy. Mol Med 2003, 9:26-36.

174. Marquis JF, Drolet M, Olivier M: Consequence of Hoechst 33342-mediated Leishmania DNA topoisomerase-I inhibition on parasite replication. Parasitology 2003, 126:21-30.

175. Das BB, Sengupta T, Ganguly A, Majumder HK: Topoisomerases of kinetoplastid parasites: why so fascinating? Mol Microbiol 2006, 62:917-927.

176. Jayanarayan KG, Dey CS: Altered tubulin dynamics, localization and posttranslational modifications in sodium arsenite resistant Leishmania donovani in response to paclitaxel, trifluralin and a combination of both and induction of apoptosis-like cell death. Parasitology 2005, 131:215-230.

177. Mollinedo F, Gajate C: Microtubules, microtubule-interfering agents and apoptosis. Apoptosis 2003, 8:413-450.

178. Hammarton TC, Mottram JC, Doerig C: The cell cycle of parasitic protozoa: potential for chemotherapeutic exploitation. Prog Cell Cycle Res 2003, 5:91-101.

179. Kidd JF, Pilkington MF, Schell MJ, Fogarty KE, Skepper JN, Taylor CW, Thorn P: Paclitaxel affects cytosolic calcium signals by opening the mitochondrial permeability transition pore. J Biol Chem 2002, 277:6504-6510.

180. Casanova M, Portales P, Blaineau C, Crobu L, Bastien P, Pages M: Inhibition of active nuclear transport is an intrinsic trigger of programmed cell death in trypanosomatids. Cell Death Differ 2008, 15:1910-1920.

181. Arnaoutov A, Dasso M: The Ran GTPase regulates kinetochore function. Dev Cell 2003, 5:99-111.

182. Askjaer P, Galy V, Hannak E, Mattaj IW: Ran GTPase cycle and importins alpha and beta are essential for spindle formation and nuclear envelope assembly in living Caenorhabditis elegans embryos. Mol Biol Cell 2002, 13:4355-4370.

183. Clarke PR, Zhang C: Spatial and temporal coordination of mitosis by Ran GTPase. Nat Rev Mol Cell Biol 2008, 9:464-477.

184. Di Fiore B, Ciciarello M, Lavia P: Mitotic functions of the Ran GTPase network: the importance of being in the right place at the right time. Cell Cycle 2004, 3:305-313.

185. Wong CH, Chan H, Ho CY, Lai SK, Chan KS, Koh CG, Li HY: Apoptotic histone modification inhibits nuclear transport by regulating RCC1. Nat Cell Biol 2009, 11:36-45.

186. Malhotra JD, Kaufman RJ: The endoplasmic reticulum and the unfolded protein response. Semin Cell Dev Biol 2007, 18:716-731.

187. Fribley A, Zhang K, Kaufman RJ: Regulation of apoptosis by the unfolded protein response. Methods $\mathrm{Mol}$ Biol 2009, 559:191-204.

188. Lustig Y, Sheiner L, Vagima Y, Goldshmidt H, Das A, Bellofatto V, Michaeli S: Spliced-leader RNA silencing: a novel stress-induced mechanism in Trypanosoma brucei. EMBO Rep 2007, 8:408-413. 
189. Das A, Zhang Q, Palenchar JB, Chatterjee B, Cross GA, Bellofatto V: Trypanosomal TBP functions with the multisubunit transcription factor tSNAP to direct spliced-leader RNA gene expression. Mol Cell Biol 2005, 25:7314-7322.

190. Ameisen JC: The origin of programmed cell death. Science 1996, 272:1278-1279.

191. Debrabant A, Nakhasi H: Programmed cell death in trypanosomatids: is it an altruistic mechanism for survival of the fittest? Kinetoplastid Biol Dis 2003, 2:7.

192. van Zandbergen G, Bollinger A, Wenzel A, Kamhawi S, Voll R, Klinger M, Muller A, Holscher C, Herrmann M, Sacks D, et al: Leishmania disease development depends on the presence of apoptotic promastigotes in the virulent inoculum. Proc Natl Acad Sci USA 2006, 103:13837-13842.

193. Nguewa PA, Fuertes MA, Valladares B, Alonso C, Perez JM: Programmed cell death in trypanosomatids: a way to maximize their biological fitness? Trends Parasitol 2004, 20:375-380.

194. Debrabant A, Lee N, Bertholet S, Duncan R, Nakhasi HL: Programmed cell death in trypanosomatids and other unicellular organisms. Int J Parasitol 2003, 33:257-267.

doi:10.1186/1756-3305-3-107

Cite this article as: Smirlis et al:: Targeting essential pathways in trypanosomatids gives insights into protozoan mechanisms of cell death. Parasites \& Vectors 2010 3:107

\section{Submit your next manuscript to BioMed Central} and take full advantage of:

- Convenient online submission

- Thorough peer review

- No space constraints or color figure charges

- Immediate publication on acceptance

- Inclusion in PubMed, CAS, Scopus and Google Scholar

- Research which is freely available for redistribution

Submit your manuscript at www.biomedcentral.com/submit 